УДК 344.65

DOI https://doi.org/10.32837/pyuv.v1i4(29).423

\author{
О. О. Торбас \\ orcid.org/0000-0002-1465-4238 \\ кандидат юридичних наук, \\ доиент кафедри крилінального проиесу \\ Національного університету «Одеська юридична акаделія»
}

\title{
ОЗНАКИ РОЗСУДУ У КРИМІНАЛЬНОМУ ПРОЦЕСІ УКРАЇНИ
}

Розсуд у праві є досить дієвим механізмом правового регулювання. Законодавець не може врегулювати всі можливі ситуації, які виникають в процесі реалізації права, а тому в окремих випадках спеціально надає суб'єктам правозастосування досить широкі повноваження в частині вибору кінцевого рішення. І галузь кримінального процесу в даному випадку не є винятком, адже можна констатувати велику кількість оцінних понять в кримінальному процесуальному законодавстві, які потребують додаткових зусиль в частині ïх застосування. Саме тому досить важливо для встановлення особливостей застосування розсуду в кримінальному процесі дослідити ознаки, які такому розсуду притаманні. Розпочати такий аналіз необхідно з дослідження позиції інших науковців щодо виділення ознак розсуду в праві.

Ю.В. Грачова, аналізуючи у власному дисертаційному дослідженні сутність судового розсуду, дійшла висновку про існування таких ознак судового розсуду:

1) правозастосовувачу надається відносна свобода вибору при прийнятті рішення;

2) право вибору при прийнятті рішення існує в межах, окреслених законол;

3) всі рішення, 3 яких правозастосовувач може прийняти будь-яке, в рівній мірі є законними, але тільки одне з них для відповідної ситуації буде обгрунтованим та справедливим;

4) існує обов'язок враховувати конкретні обставини вчиненого суспільно небезпечного діяння $[1$, c. 145$]$.

О.В. Корабліна, аналізуючи судовий розсуд, встановила такі ознаки, які притаманні даному явищу:

1) правозастосовувачу надається відносна свобода вибору при прийнятті рішення, пов'язаного із застосуванням даної норми в конкретній життєвій ситуації;

2) правозастосовувачу надається право вибору при прийнятті рішення в межах, встановлених законол;

3) всі рішення, 3 яких правозастосовувач може вибрати будь-яке, в рівній мірі є законнили та обгрунтованили;

4) має відбуватися обов'язкове врахування конкретних обставин вчиненого суспільно небезпечного діяння при здійсненні вибору одного 3 можливих варіантів рішення [2, с. 246].
Можна помітити, що підходи Ю.В. Грачової та О.В. Корабліної є досить подібними. Проте у вказаних позиціях існує суттєва відмінність, на яку необхідно звернути увагу. Так, Ю.В. Грачова стверджує, що всі рішення, які можуть бути обрані правозастосовувачем, є законними, проте лише одне 3 них є обгрунтованим та справедливим. О.В. Корабліна до цієї проблеми підходить дещо інакше, зазначаючи, що всі можливі рішення мають бути і законними, і обгрунтованими. Такий підхід видається дещо радикальним та, можливо, не зовсім відповідає суті розсуду. Якщо всі альтернативи, які доступні правозастосовувачу, є одночасно і законними, і обгрунтованими, то взагалі зникає необхідність застосування розсуду.

А.С. Скударнов, вивчаючи проблему розсуду 3 позиції людиноцентристського праворозуміння, робить досить цікаві висновки щодо переліку ознак, які притаманні розсуду в праві:

1) розсуд здійснюється будь-яким суб'єктом, а не лише уповноваженими на те особами;

2) розсуд має цілеспрямований характер;

3) розсуд є елементом індивідуального правового регулювання;

4) розсуд проявляється в правомірній поведінці;

5) розсуд має творчий характер [3, с. 30].

I.I. Поляков, підсумовуючи власне бачення сутності розсуду в праві, дійшов висновку про наявність таких ознак розсуду:

1) легальності (спроможність суб'єктивного розсуду представлена об'єктивним правом);

2) інтелектуально-вольового характеру;

3) правоздатності і дієздатності суб'єкта розсуду;

4) цілеспрямованості суб'єкта розсуду (розсуд завжди спрямований на вибір поведінки, необхідної для досягнення конкретної мети) [4, c. 235].

П.В. Марков згадує такі ознаки:

1) відповідність загальноправовим принципам має виступати в якості цілі для судового розсуду та судової діяльності в цілому;

2) судовий розсуд здійснюється (або хоча б отримує зовнішнє вираження) у формі логічної аргументації, оскільки в такий спосіб суд зможе продемонструвати відповідність прийнятого ним рішення правовим нормам; 
3) суд приймає рішення відповідно до своїх особистих переконань, розсуд суду означає його свободу від будь-якого впливу - політичного, економічного тощо [5, с. 74].

Оцінивши підходи різних науковців до проблеми визначення ознак розсуду в праві, можна спробувати встановити характеристики, які притаманні розсуду в кримінальному процесі. Спочатку необхідно зазначити, що розсуд - це повноваження, а не право. У даному випадку розсуд має досліджуватися не як спосіб прийняття рішень, а як можливість прийняття юридично значущих для інших учасників правовідносин рішень. Кримінальний процес $є$ публічною галуззю права, тому необхідно оцінювати саме можливості застосування правових норм уповноваженими на те суб'єктами. Отже, аналіз розсуду через оцінку повноважень дозволяє зробити ще один досить важливий висновок. Розсуд в кримінальному процесі як повноваження (не спосіб прийняття рішення) притаманний лише уповноваженим суб'єктам слідчому судді, суду, слідчому, прокурору та ін., тобто тим суб'єктам в кримінальному провадженні, які реалізують владні повноваження. Суб'єктами розсуду в кримінальному процесі не можуть бути інші учасники кримінальних процесуальних правовідносин, які реалізують лише права та виконують обов'язки (підозрюваний, обвинувачений, захисник, потерпілий тощо).

У такому разі важливо також встановити відмінність між розсудом у виборі власних прав та розсудом при реалізації владних повноважень. Наприклад, підозрюваний, подаючи до слідчого клопотання в порядку ст. 220 КПК, створюе обов'язок слідчого надати відповідь не пізніше трьох днів з моменту подання відповідного клопотання. Проте тут відсутній розсуд у його правовому розумінні, адже, як вже було зазначено, розсуд також пов'язаний виключно з можливістю реалізації владних повноважень, якими наділені лише відповідні суб'єкти. Створення обов'язків для інших учасників кримінальних процесуальних правовідносин шляхом реалізації власних прав не робить таких учасників суб'єктами розсуду в кримінальному процесі.

Виходячи з позиції, що в кримінальному процесі розсуд пов'язаний з повноваженнями конкретного суб'єкта, можна встановити таку ознаку даного правового явища: розсуд полягає в прийнятті обов'язкових для виконання юридично значущих рішень. Результатом розсуду завжди має бути певне юридичне рішення, винесення якого має створювати юридичні права та обов'язки для інших учасників кримінального провадження. При цьому таке рішення не обов'язково має бути оформленим як окремий процесуальний документ або бути пов'язаним з вирішенням кримінального провадження по суті. Наприклад, слідчий на власний розсуд може прийняти рішення про проведення допиту свідка, наслідком чого стане обов'язок такої особи з'явитися для участі у слідчій (розшуковій) дії, повідомити про наявність поважних причин неявки тощо. При цьому таке рішення не буде оформлюватися у вигляді окремого документа.

Зазначена ознака також допомагає розділяти розсуд як метод та розсуд як результат. Якщо в результаті розсуду уповноваженою особою буде прийняте рішення, яке не створюватиме для будь-якого учасника кримінальних правовідносин обов'язків, то некоректним буде твердження, що відповідним уповноваженим суб'єктом було застосовано розсуд. Наприклад, слідчий, аналізуючи та перевіряючи версії вчинення кримінального правопорушення, може внаслідок розсуду робити для себе певні висновки. У такому разі слідчий застосуватиме розсуд саме як метод прийняття рішення, що притаманно будь-кому. Якщо в результаті такої діяльності слідчим буде прийняте рішення про проведення додаткових слідчих (розшукових) чи будь-яких інших процесуальних дій або застосування до осіб заходів забезпечення тощо, то слідчий виступатиме саме в якості суб'єкта розсуду, адже він прийме дозволене законом рішення, яке виступить в якості юридичного факту та потягне за собою створення певних обов'язків для інших учасників кримінального провадження.

Наступною ознакою, на яку посилалась значна кількість науковців, є відносна свобода розсуду у кримінальному процесі. Розсуд можливий лише в певних межах, які чітко визначені законодавчим актом. Проте в даному випадку одразу необхідно зауважити, що такі межі не обов'язково мають бути встановлені лише відповідною нормою права, а і всім нормативно-правовим актом. Розсуд, як правило, застосовується у випадках застосування законодавцем відносно визначених норм, які вимагають від уповноважених суб'єктів прийняття найбільш оптимального рішення, яке відповідає фактичним обставинам провадження. Однак науковці також неодноразово зазначали, що розсуд також може застосовуватись уповноваженими суб'єктами і у випадках подолання прогалин нормативно-правового акта. Прогалини в праві, попри їхній негативний вплив на порядок правозастосування, завжди були присутніми в будь-якому нормативно-правовому акті, і не схоже, що така тенденція може змінитися.

Також, аналізуючи дану характеристику, необхідно вказати, що уповноважений на розсуд суб'єкт кримінального провадження завжди обмежений у своєму розсуді кримінальним процесуальним законодавством та не має права вийти за такі межі. Саме цим пояснюється відмінність між розсудом та зловживанням правом. Така 
вимога дозволяє сформулювати наступну ознаку, яка полягає у тому, що розсуд має бути законним. Розсуд надає право уповноваженим суб'єктам обирати один з декількох способів реалізації певного правового положення. Проте ключовим в даному випадку має бути той факт, що будь-яке з можливих рішень повністю відповідає вимогам норми права, тобто є законним. Отже, якщо норма права передбачає лише один законний варіант поведінки, то розсуд відсутній, а будь-які відхилення від правової норми вказують на незаконність поведінки уповноваженого суб’єкта.

Якщо ідеться про законний розсуд, то в якості окремої ознаки необхідно підкреслити зв'язок між розсудом та кримінальним процесуальним законодавством. Галузь кримінального процесу з урахуванням специфіки методів та форм правового регулювання містить в собі досить велику кількість обмежень. Особливо ці обмеження стосуються повноважень владних суб’єктів, на яких покладається обов'язок розслідування, розгляду та вирішення кримінальних правопорушень. 3 огляду на це можливості вільного застосування власних повноважень такими суб'єктами порівняно з іншими галузями права значно обмежені. Чітке та неухильне дотримання процедури здійснення кримінального провадження є однією з головних гарантій забезпечення прав та законних інтересів учасників кримінального провадження. Отже, будь-яке незаконне відхилення від таких процедур може бути підставою для скасування процесуальних рішень, визнання доказів неналежними тощо. Кримінальні галузі права з урахуванням власної специфіки мають суттєво вужчі можливості щодо застосування розсуду.

Також серед ознак, які притаманні кримінальному процесуальному розсуду, необхідно вказати інтелектуально-вольовий характер такої діяльності. Обов' язково необхідно підкреслити саме зв' язок цих двох компонентів, які діють у симбіозі i надають можливість застосувати розсуд відповідним уповноваженим суб'єктам. Розсуд базується на правильному тлумаченні та застосуванні відповідної правової норми, в чому і проявляється інтелектуальна характеристика розсуду. За таких умов застосування розсуду потребує використання інтелектуального механізму (огляду фактів, обгрунтування позиції, оцінки фактів, здійснення переконання, формування висновка) [6, с. 16]. Водночас розсуд нерозривно пов'язаний із суб'єктом, який його застосовує, тому в будь-якому разі має також бути присутній вольовий елемент.

Також необхідно вказати на ще одну характеристику, яка в деяких випадках може мати ключове значення при прийнятті уповноваженим суб'єктом відповідного рішення. Ідеться про необхідність врахування обставин конкретного кримінального провадження при застосуванні розсуду в кримінальному процесі. Сама ідея необхідності визначення розсуду в процесі правозастосування пов'язана 3 тим, що на законодавчому рівні неможливо спрогнозувати всі можливі ситуації, які можуть виникнути на практиці. Отже, уповноважені особи при застосуванні розсуду повинні враховувати конкретні обставини кожного кримінального провадження, давати оцінку кожній обставині кримінального правопорушення, враховувати особливості всіх учасників кримінального провадження тощо. Рішення, яке виглядає найбільш оптимальним в одному кримінальному провадженні, може абсолютно не відповідати обставинам іншого провадження. Як приклад можна навести положення ч. 4 ст. 182 КПК України, відповідно до якого слідчий суддя або суд при визначенні розміру застави для підозрюваного чи обвинуваченого мають враховувати матеріальний стан осіб, до яких буде обрана застава, адже розмір застави не може бути завідомо непомірним для них. Отже, навіть в межах одного кримінального провадження до двох підозрюваних може бути обраний різний розмір застави, адже помірний розмір для одного може бути непомірним для іншого. Лише при врахуванні обставин конкретного кримінального провадження можна вести мову про те, що розсуд в кримінальному процесі виконує покладене на нього завдання.

Також окремо мають бути згадані ознаки, які впливають на розсуд в кримінальному процесі. Дослідивши думки та позиції інших вчених, можна зробити висновок, що на розсуд в кримінальному процесі впливають:

- засади кримінального процесу;

- професійний досвід правозастосовувача;

- судова та слідча практика;

- моральні та етичні характеристики суб'єкта правозастосування.

Також цілком очевидним є те, що на розсуд (особливо на його межі) впливають правові норми. Проте обмеження розсуду нормою права було описане в якості окремої ознаки (законності), тому в додатковому виділенні такої характеристики немає сенсу.

Засади кримінального провадження $€$ невід'ємною частиною всього кримінального процесу та мають значний вплив на всі процеси, що в ньому відбуваються. Засади як певні фундаментальні положення вказують на спрямованість ідеї законодавця в частині застосування всіх положень КПК України. Законодавець прямо передбачив обов'язок уповноважених суб'єктів застосовувати засади кримінального провадження у разі відсутності або неоднозначності правового регулювання будь-яких кримінальних процесуальних відносин. Сама процедура застосування принципів кримінального провадження чітко не прописана у законодавстві, що тягне за собою 
складність в процесі імплементації в практику даного положення КПК України. Проте в цьому і полягає сутність розсуду в кримінальному процеci, відповідно до якого уповноваженому суб’єкту описуються лише певні межі застосування норми, проте прийняття рішення в конкретному кримінальному провадженні має залежати від суб’єкта кримінального провадження, який, крім іншого, також повинен враховувати засади кримінального провадження.

Оцінюючи характеристики, які можуть впливати на рішення уповноваженої особи, також необхідно надати оцінку професійному досвіду особи, до повноважень якої належить застосування розсуду в кримінальному процесі. Не можна переоцінити досвід, який набув, наприклад, слідчий або прокурор на власній посаді, а також значення такого досвіду при розслідуванні подібних кримінальних правопорушень. Крім того, уповноважені особи, аналізуючи результати кримінального провадження, роблять висновки щодо власних прорахунків при застосуванні правових норм і коригують власний підхід до аналогічних ситуацій 3 метою отримання позитивного результату або недопущення помилок, які трапилися в минулому.

У кримінальному процесі досить складно переоцінити значення слідчої та судової практики для прийняття конкретного процесуального рішення (особливо в процесі застосування розсуду). Як відомо, одним з основних завдань оновленого Верховного Суду є уніфікація судової практики шляхом прийняття рішень, в яких би містились правові позиції з найбільш типових чи значимих проваджень, які є обов'язковими для інших учасників правовідносин. Також досить важливе значення має практика судів першої та апеляційної інстанції, з якою постійно знайомляться правозастосовувачі через Єдиний державний реєстр судових рішень. На даний момент можна констатувати, що, крім випадків застосування абсолютно нових норм кримінального процесуального законодавства, в більшості ситуацій можна знайти схожі кримінальні провадження в ЄДРСР, а отже, можна відшукати і аргументацію суду чи прокурора щодо особливостей застосування тієї чи іншої процесуальної норми. Аналогічна ситуація спостерігається і в частині аналізу та застосування слідчої практики. При цьому слід підкреслити, що значення практики в процесі застосування розсуду дійсно велике, навіть попри відносне ігнорування даного питання як науковцями, так і практиками.

Останньою в переліку, але далеко не останньою за значенням є така ознака, як моральні та етичні характеристики суб'єкта правозастосування. Процес застосування розсуду нерозривно пов'язаний з суб'єктом, який цей розсуд застосовує. Отже, особистісні характеристики завжди будуть мати вплив на результати прийнятого рішення. Різнитися може лише сила впливу таких факторів на остаточне рішення та у разі низького рівня етичності та моральності суб'єкта правозастосування деформація остаточного рішення і його віддаленість від мети розсуду.

Також надважливою характеристикою розсуду, на яку вказували інші науковці, є кінцева мета розсуду, тобто той бажаний результат, якого планується досягти в процесі застосування розсуду в кримінальному процесі.

У правовій доктрині науковці досить часто вказували на таку кінцеву мету розсуду, як ефективність, доцільність, справедливість тощо. Очевидно, що з такими позиціями досить важко сперечатися. Проте проблеми виникають в процесі глибшого аналізу вказаних понять. I ефективність, і доцільність, і справедливість є занадто оцінними поняттями, в яких майже неможливо встановити межі, особливо в такій регульованій сфері, як кримінальний процес. Крім того, всі ці поняття є занадто суб'єктивними, адже, наприклад, те рішення, яке одному учаснику кримінального провадження видається справедливим, іншому таким не здається. 3 огляду на це використання настільки оцінних понять буде зайвим, особливо за умови, що саме поняття "розсуд» також є оцінним.

Водночас встановити єдину i чітку кінцеву мету розсуду, яка б мала лише одне тлумачення, також неможливо. Проте необхідно використати такі межі, які дозволять мінімізувати некоректне або занадто широке тлумачення кінцевої мети застосування розсуду. У такому разі більш доцільним виглядає використання поняття «інтерес» як мети розсуду. Так, аналіз категорії «інтерес» в кримінальному процесі знайшов своє відображення в достатній кількості наукових досліджень, що значно полегшує оперування таким поняттям [7; 8]. Крім того, законодавець у ст. 2 КПК України також вказує на інтерес як на одне із завдань кримінального провадження, що дозволяє стверджувати про певне легальне підгрунтя даної правової категорії.

У наукових роботах виділяються два таких види інтересу у кримінальному провадженні: інтерес приватний та інтерес публічний. Розсуду в кримінальному процесі також повинна бути притаманна така ознака, як захист приватних та публічних інтересів. При цьому, як і у всьому кримінальному провадженні, при застосуванні розсуду має бути збережений баланс цих двох інтересів.

3 одного боку, слідчий, прокурор, слідчий суддя, суд повинні обрати таке рішення, яке найбільше відповідає інтересам окремої особи у кримінальному провадженні. Такою особою може бути як підозрюваний, так і потерпілий. 3 іншого боку, уповноважена особа завжди повинна враховувати 
суспільні інтереси при застосуванні розсуду, адже в значній мірі саме для захисту суспільства здійснюється кримінальне провадження. А. Барак, аналізуючи роль судді при застосуванні розсуду, цілком слушно зазначає, що суддя повинен знати настрій суспільства, в якому він служить суддею. Він повинен знати націю та різноманіття їі проблем, тому він повинен перебувати в контакті 3 широкою публікою [9, с. 34]. «Не варто кидатися з одних крайнощів в інші. Не варто будувати стіну між суддею та суспільством, в якому він діє. Суддя - частина свого народу. <..> Суддя - громадянин, гарний суддя повинен бути гарним громадянином. Він повинен робити всій вклад в будівництво свого суспільства» [9, с. 34$]$.

Отже, можна зробити висновок, що кінцевою метою розсуду в кримінальному процесі є забезпечення приватних та публічних інтересів. Крім того, таке забезпечення має бути збалансованим, адже саме баланс між цими двома інтересами гарантує виконання завдань кримінального провадження, що є кінцевою метою будь-якої кримінальної процесуальної діяльності.

Підсумовуючи все зазначене, можна констатувати, що розсуд в кримінальному процесі можна охарактеризувати так:

- розсуд є повноваженням;

- розсуд полягає в прийнятті обов'язкових для виконання юридично значущих рішень;

- розсуд передбачає відносну свободу;

- розсуд має бути законним;

- розсуд має відповідати вимогам кримінального процесуального законодавства;

- розсуд має інтелектуально-вольовий характер;

- при застосуванні розсуду мають враховуватись обставини конкретного кримінального провадження;

- у кримінальному процесі на розсуд впливають засади кримінального процесу, професійний досвід правозастосовувача, судова та слідча практика, моральні та етичні характеристики суб'єкта правозастосування;

- кінцевою метою розсуду є якнайкраще забезпечення приватних та публічних інтересів.

\section{Jimepamypa}

1. Грачева Ю.В. Судейское усмотрение в реализации уголовно-правовых норм: проблемы законотворчества, теории и практики : дисс. ... докт. юрид. наук : 12.00.09. Москва, 2011. 535 с.

2. Кораблина О.В. Понятие и признаки судейского усмотрения в российском уголовном праве. Вестник АГТУ. Серия «Гуманитарные науки». 2007. № 3(38). C. 242-248.

3. Скурданов А.С. $К$ вопросу об усмотрении в праве. Сибирский юридический вестник. 2012. № 3 (58). С. 27-33.

4. Поляков I.I. Розсуд у праві: поняття, ознаки і види. Актуальні проблеми політики : зб. наук. пр. Одеса : Фенікс, 2009. Вип. 38. С. 233-239.
5. Марков П.В. Правовая природа и условия осуществления судебного усмотрения : дисс. ... канд. юрид. наук : 12.00.01. Москва, 2012. 180 с.

6. Ермакова К.П. Пределы судебного усмотрения : дисс. ... канд. юрид. наук : 12.00.01. Москва, 2010. 212 c.

7. Тітко I.A. Нормативне забезпечення та практика реалізації приватного інтересу у кримінальному процесі України : автореф. дис. ... докт. юрид. наук : 12.00.09. Харків, 2016. 37 с.

8. Рибалко В.О. Оцінне поняття «суспільний інтерес» як підстава для відмови у затвердженні угоди про примирення і визнання винуватості. Науковий вісник Львівського державного університету внутрішніх справ. 2014. № 2. С. 356-366.

9. Барак А. Судейское усмотрение / пер. с англ. Москва : Норма, 1999. с. 364.

\section{Анотація}

Торбас О. О. Ознаки розсуду у кримінальному процесі України. - Стаття.

У статті досліджуються ознаки розсуду у кримінальному процесі України. Автор аналізує позиції науковців щодо визначення ознак розсуду в праві та на підставі наукових розробок робить висновок щодо ключових характеристик розсуду у кримінальному процесі. У статті зазначається, що розсуд в кримінальному процесі можна охарактеризувати так: розсуд $\epsilon$ повноваженням; розсуд полягає в прийнятті обов'язкових для виконання юридично значущих рішень; розсуд передбачає відносну свободу; розсуд має бути законним; розсуд має відповідати вимогам кримінального процесуального законодавства; розсуд має інтелектуально-вольовий характер; при застосуванні розсуду мають враховуватись обставини конкретного кримінального провадження; у кримінальному процесі на розсуд впливають засади кримінального процесу, професійний досвід правозастосовувача, судова та слідча практика, моральні та етичні характеристики суб'єкта правозастосування; кінцевою метою розсуду $\epsilon$ якнайкраще забезпечення приватних та публічних інтересів.

При цьому автор обгрунтовує кожну з характеристик, надаючи приклади і посилання на норми КПК України. Наприклад, при дослідженні такої ознаки розсуду в кримінальному процесі, як врахування обставин конкретного кримінального провадження, автор використовує в якості ілюстрації ч. 4 ст. 182 КПК України, відповідно до якої слідчий суддя або суд при визначенні розміру застави для підозрюваного чи обвинуваченого мають врахувати матеріальний стан осіб, до яких буде обрана застава, адже розмір застави не може бути завідомо непомірним для них. Автор робить висновок, що лише при врахуванні обставин конкретного кримінального провадження можна вести мову про те, що розсуд в кримінальному процесі виконує покладене на нього завдання. Схожі приклади та висновки робляться і щодо інших зазначених характеристик. Це підтверджує правильність кінцевих висновків.

Ключові слова: розсуд у кримінальному процесі, ознаки розсуду.

\section{Summary}

Torbas 0.0 . Features of discretion in criminal process of Ukraine. - Article.

The article discusses features of discretion in criminal process of Ukraine. The author analyses positions of scientists in determining features of discretion in law, 
and on the basis of scientific researches makes his own conclusion about key characteristics of discretion in criminal proceedings. In article author proves that discretion in criminal proceedings can be characterized as follows: discretion is a power; discretion consists in making legal decisions that are obligatory; discretion implies relative freedom; discretion must be lawful; discretion must comply with the requirements of criminal procedural law; discretion is intellectual and willing activity; circumstances of specific criminal proceeding must be taken into account when applying discretion; in criminal proceedings, the principles of criminal process, professional experience of law enforcer, judicial and investigative practice, moral and ethical characteristics of the law enforcer have an influence on discretion; ultimate goal of discretion is to secure private and public interests.
At the same time, author substantiates each of the characteristics, providing examples with references to the articles of theCPC of Ukraine. For example, during the research of such feature as taking into account all circumstances of particular criminal proceedings, author uses as an example part 4 of Art. 182 of the CPC of Ukraine, according to which investigating judge or court, when determining the amount of bail for the suspect or accused, must take into account financial status of the persons to whom the bail is selected, since the bail amount cannot be deliberately exorbitant for them. In this case, author concludes that after taking into account all of circumstances of a particular criminal proceeding we can state that discretion in the criminal process fulfilled its task. Similar examples and conclusions are drawn with respect to other mentioned characteristics, which confirms the correctness of final conclusions.

Key words: criminal proceedings, signs of judgment. 